\title{
TO BE OR NOT TO BE OF GOOD FAME, THAT IS THE QUESTION
}

\section{David Pugsley*}

Key words: Duels; Breach of the Peace; Justices of the Peace Act, 1361; to be or not to be

A good conference has interesting papers, followed by a lively discussion, stimulating new ideas and theories. The 2015 conference of the Southern African Society of Legal Historians was a good conference. My own paper is being published elsewhere, but the discussion at that conference about the law of duelling stimulated the following thoughts.

Duel comes from the Latin, duellum, a variant of bellum, war. A duel is a private war. Duelling was (and still is) illegal. It is a breach of the peace. And anyone caught about to fight a duel might be taken before the magistrates and bound over to keep the peace, normally for one year. The security required was sometimes very high. In 1798 when Lieut Bromley, of the Marines, and Mr Palmer, of Ayre street, Piccadilly, were caught planning a duel near Upnor Castle, Kent, Palmer was required to give security of $£ 2,000$ ( $£ 1,000$ himself, and two sureties of $£ 500$ each), because he would not give his word of honour that the matter would not be pursued. Bromley was bound over in the sum of $£ 500$ and two sureties of $£ 250$ each. (Palmer had horsewhipped Bromley for sending a very impertinent letter to his wife. ${ }^{1}$ )

$1 \quad$ The Times, 7 Sep 1798.

* Professor Emeritus, University of Exeter. 
In 1806 Francis Jefferies, of Edinburgh, and Thomas Moore, of Bury Street, St James, were caught in the act of fighting a duel near Chalk Farm (near the modern underground station on the Northern line). The principals were bound over in the sum of $£ 400$ each and two sureties of $£ 200$ each, and the seconds were bound over in the sum of $£ 200$ each. The pistols were confiscated and it was found later that neither of them had been loaded with ball, so that no harm could have been done if they had fired. (The cause of the duel is not recorded. ${ }^{2}$ ) These are enormous sums for that period.

It was a misdemeanour for one man to challenge another to fight a duel. Between 1800 and 1805 there were at least eight convictions for this offence, leading to terms of imprisonment between three weeks and twelve months, and fines up to 400 guineas. $^{3}$ In 1823 Edward Divett, for many years one of the MPs for Exeter, received a challenge from someone he had never met (perhaps a dissatisfied elector) and prosecuted him. His challenger was fined $£ 20$, sent to prison for six months, and bound over to keep the peace for two years afterwards in the sum of $£ 200$ and two sureties of $£ 100$ each. ${ }^{4}$

The magistrates' power to bind people over to keep the peace and to be of good behaviour is derived from the Justices of the Peace Act $1361 .{ }^{5}$ It is a celebrated statute which may or may not contain the vital word "not". ${ }^{6}$ It gives the magistrates power to bind over "all them that be of good fame", or perhaps "all them that be not of good fame". None of the duellists who were bound over raised the issue. It was not raised until 1913. George Lansbury, ${ }^{7}$ a future leader of the Labour Party in the 1930s, was elected as MP for Bow and Bromley in the second general election in 1910. He was a strong supporter of the suffragette movement. On 25 June 1912 he caused a scene in the House of Commons on their behalf and was ordered by the Speaker to leave the House. He resigned his seat and immediately fought a byelection for it on the issue of women's rights, but lost. He continued to campaign and address meetings on their behalf. On 10 April 1913 he addressed a meeting in the Albert Hall and called on his audience to stand shoulder to shoulder with the militant women. Let them burn and destroy! He was prosecuted under the 1361 statute and bound over by the magistrate to be of good behaviour in the sum of $£ 1,000$ himself and two sureties of $£ 500$ each, or to serve three months in prison. He appealed to the Divisional Court, ${ }^{8}$ where he was represented by Montague Shearman KC, a brilliant

5

6

7

8
The Times, 12 Aug 1806.

Banks 2010: 154-155.

Exeter Flying Post, 22 Jan 1824. He was released from prison on 14 Jun with a royal pardon for the unexpired portion of his sentence (only two weeks).

34 Edward III, cap 1.

Megarry 1955: 340.

See Postgate 1951: esp at 130-131.

Lansbury v Riley [1914] 3 KB 229. 
scholar and keen antiquarian. ${ }^{9}$ He went back to the original Statute Roll, which did not contain the word "not", and argued that it was confined to "pillors and robbers" from across the seas: those who were of good fame might simply be bound over, the others ${ }^{10}$ duly punished. The statute clearly had no application to the case of the defendant. The court did not call on the Attorney General to reply and rejected the appeal out of hand: whatever was the original intention of the statute, and whether or not it contained the word "not", the modern cases were clear and it was much too late to go behind them to look at the original text, though Lush J did say that "there was great force in Mr Shearman's contention as to the true meaning of this obscure statute". (Lansbury refused to be bound over and was sent to prison. He immediately went on a hunger-and-thirst strike and was quickly released.)

If Shearman had thought of it he might have addressed the court as follows: "To be, or not to be. That is the question. Whether the power to bind over applies to all them that be of good fame, or to all them that be not of good fame." There is a precedent for "To be or not to be, that is the question" in Hamlet's famous soliloquy in Act III, scene 1. It is traditionally said to be a suicide speech, and it may be far too late to convince anyone to the contrary, but a careful study of the text itself leads to a different conclusion.

What would any unbiased person think who heard the speech for the first time, with no prior knowledge of it? It would be very difficult to find any such person. What would an intelligent visitor from Mars make of it? At the words "To be or not to be" would his reaction be: the speaker is thinking of committing suicide? Or would it be: to be or not to be what? And wait for the next two lines which give the answer: "to be or not to be noble-minded?" And the choice is set out expressly and clearly: either to suffer the slings and arrows of outrageous fortune (the pacifist option), or to take arms against a sea of troubles and by opposing end them (the bellicose option). ${ }^{11}$ Suicide is not an option in this speech.

9 For example, at the nomination ceremony for High Sheriffs in November 1905 he represented Edward Carter, of Ryde, Isle of Wight, who wished to be struck off the list. Shearman tracked down in the Privy Council archives a charter of Charles I, dated 15 Aug 1626 and addressed to Lord Conway, Captain of our Isle of Wight, exempting the inhabitants of the island from service as High Sheriffs of Hampshire. The charter had been forgotten for years, if not centuries, but a transcription was produced in court on the morning of the ceremony. However, the court decided to leave Carter's name on the list. See The Times, 14 Nov 1905. (The charter is now in the National Archives, PC 8/617.) When Shearman came as an assize judge on the Western Circuit in 1925 he contributed an article on "The Western Circuit in the $16^{\text {th }}$ Century" in The Dorset Year-book, 1925 at 24-26.

10 Modern versions of the statute have "the other duly to punish", but the text clearly has "les aut's" (plural).

11 This is very strange. Not even King Canute's courtiers suggested that he should take arms against the sea. A more understandable choice would be: to take arms against the slings and arrows of outrageous fortune, or to suffer from a sea of troubles (overwhelmed, drowned). Is there a touch of madness here? 
There is nothing about suicide in this speech. Hamlet had considered suicide in Act I, scene 2, after the marriage between his mother and his uncle and before his meeting with his father's ghost, and immediately rejected the idea: "Oh that the Everlasting had not fixed his canon 'gainst self-slaughter." But he had fixed it; it was forbidden. That was recognised by Imogen in Cymbeline, Act III, scene 4: "[A] gainst self-slaughter there is a prohibition so divine that cravens my weak hand." She had a way round it. She asked Pisanio to do it for her; but he refused. Hamlet could have asked Horatio, but he was not present during the soliloquy.

After Hamlet's meeting with his father's ghost in Act I, scene 5, there is no longer any question of self-slaughter. (Suicide was not in Shakespeare's vocabulary and does not appear in English for another half century. ${ }^{12}$ ) The choice is now between suffering in silence and taking revenge: "If thou didst ever thy dear father love, revenge his foul and most unnatural murder."

For the rest of the play Hamlet vacillates between cowardice and action. He is worried that if he takes revenge and kills the new king, Claudius, he may have to pay for it in the next life. "There's the rub; for in that sleep of death what dreams may come, when we have shuffled off this mortal coil, must give us pause." There is nothing about suicide here. The question is not: "to shuffle off this mortal coil", or "not to shuffle off this mortal coil"; but simply what happens after death. His father's ghost had already done enough to frighten him, without giving him any actual details. "The dread of something after death ... puzzles the will." Macbeth faced a similar concern but arrived at a different conclusion: if he killed the king, Duncan, he might have to pay for it in the next life, but if success was assured "We'd jump the life to come" (Act I, scene 7).

The theme of action or inaction runs throughout the speech. "Who would bear ... the law's delay ... when he himself might his quietus make with a bare bodkin?"13 This does not mean: "Who would put up with the law's delay when he could commit self-slaughter?" It means: "Who would put up with the law's delay when he could dispose of the matter himself, by self-help, by fighting back?"14 The bare bodkin

12 I remember having lunch in All Souls with David Daube in 1966 when he was talking about his ideas on suicide which became his article on "The Linguistics of Suicide" in Philosophy and Public Affairs.

13 Who could dispose of serious problems with a bare, that is a simple, bodkin? Answer: the monarch, when he pricked the roll of High Sheriffs with a bodkin to dispose of, or to avoid, disputes arising from tampering with the roll. The practice is said to have started with Elizabeth I. The lawyers in the audience would have understood the point. Quietus is also found in the contest of sheriffs. The had to present their accounts in the Court of Exchequer at the end of their year of office. The Quietus Roll would be annotated at the end: et quietus est, the account is settled. See the Quietus Roll of John Cotton, High Sheriff of Cambridgeshire, 1591-1592, in Strazicker 2007: 6, where there is also a photo on the front cover of the bare bodkin now used by the Queen in the pricking ceremony.

14 Should the relatives and friends of the victims of the Hillsborough disaster in 1989 have suffered in silence, or committed suicide, or fought back? They fought back. 
follows the reference to taking arms at the beginning of the speech, not for selfslaughter, but against a sea of troubles, to end them. Like the dagger which Macbeth saw before him the bare bodkin was to kill the king, not himself.

"Who would bear ... the pangs of despised love ... when he himself might his quietus make with a bare bodkin?" This does not mean: "If your girl-friend says 'No', why put up with it when you could commit suicide?" That would be a quite excessive reaction, with nothing noble-minded about it at all. Remember the beginning of the speech: "the slings and arrows of outrageous fortune." If your girl-friend says "no", that is a disappointment, but it is not an outrage; but if your uncle murders your father, marries your mother and becomes king in your place, that is an outrage. And look at the words here: "despised love." Hamlet's love may have been rejected Polonius says repulsed - but there is no evidence that it was despised. Nor is there any evidence that he was suffering any pangs as a result. Polonius says that he was, but Polonius had not met the ghost of Hamlet's father. We know, because Hamlet told us so in his soliloquy in Act I, scene 2, that his mood was caused by the precipitate marriage between his mother and his uncle. "Oh, most wicked speed, to post with such dexterity to incestuous sheets!” Incestuous appears four times in the play (and only once elsewhere in Shakespeare, in King Lear). This is the despised love, the love that Hamlet despises. "But break, my heart, for I must hold my tongue." This is the heart-ache, these are the pangs of despised love. Who would bear them, when he could bring them to an end by killing the "incestuous, murderous, damned Dane" (Act V, scene 2). ${ }^{15}$

The speech ends with a reference to "enterprises of great pith and moment" which "lose the name of action". Suicide is not an enterprise of great pith and moment, but revenge, killing the king, might be.

Hamlet does not make up his mind. His train of thought is interrupted when he sees Ophelia, who has been on stage quietly reading a book all the time. Like many indecisive men, he puts off the decision until he has more evidence; and he organises the play within the play, the Mouse-trap.

During the soliloquy Claudius and Polonius were standing and listening in the wings. Claudius did not think that the speech was like madness or about love. He saw in it a threat to himself, some danger, and took a quick determination, unlike Hamlet's resolution which was "sicklied o'er with the pale cast of thought", to send him to England. And, like King Herod, he had two reasons: publically to collect danegeld; privately to have him killed. Of all the films of the soliloquy the best version is by Kenneth Branagh in 1996. It has a quick glimpse of the two men watching in the wings before the soliloquy starts. When Hamlet reaches the bare bodkin, he holds it away from himself, menacingly, and there is a quick shot of Claudius' reaction: he knew what this was all about - not suicide, but revenge.

$15 C f$ D 92 30pr. Hamlet's father's ghost actually calls Claudius "that incestuous, that adulterate beast" (Act I, scene 5). 
Polonius, who knew nothing about the murder, still thought that the speech was a consequence of neglected love, but he said nothing about it being about suicide.

Ophelia had been on stage throughout the speech, pretending to read a book, but listening to Hamlet's every word. She picked up, twice, his reference to a noble mind. She made her feelings for him very clear in a short soliloquy after he had left the stage. She clearly did not despise him; and during the previous dialogue she had cried out: "Oh, help him, you sweet heavens." If she had thought that he was contemplating suicide, she would surely have intervened; but she did not.

This is not a suicide speech. It is not about self-slaughter; it is about self-help. The difficulty arises from the first six words. No-one thinking of committing suicide speaks like that. ${ }^{16}$ How are we to explain them? Shakespeare knew that duelling was a breach of the peace (Titus Andronicus, Act II, scene 1, Aaron interrupting a duel between Demetrius and Chiron: "these lovers will not keep the peace"). The Justices of the Peace Act might apply. Is it possible that there had been a recent case involving the wording and interpretation of the statute; that counsel had referred to the variant manuscript readings, with and without "not", and said "To be or not to be, that is the question"; and that those words in Hamlet are a little legal in-joke? ${ }^{17}$

\section{ABSTRACT}

Duels are a breach of the peace, punished for centuries under the Justices of the Peace Act, 1361, which however may or may not contain the word not. This may be the background to Hamlet's soliloquy, To be or not to be, which is not a suicide speech: Hamlet knew that self-slaughter was forbidden, and none of the three actors listening to him, Ophelia, Claudius and Polonius, interpreted it as a suicide speech.

\section{BIBLIOGRAPHY}

Banks, Stephen (2010) A Polite Exchange of Bullets (Woodbridge)

Daube, David (1972) The Linguistics of Suicide, Philosophy and Public Affairs (1972): 387-437

Justinianus, Flavius (533) Digesta (Constantinople)

Megarry, RE (1955) Miscellany-at-Law (London)

Postgate, Raymond (1951) The Life of George Lansbury (London, New York, Toronto)

16 We might use those words if we received a dinner invitation with a reply slip: "We shall be/shall not be coming to the dinner. Delete as appropriate." We might then say: "To be or not to be, that is, the question whether we shall be coming or not."

17 The beginning of the speech is curious, in particular the words "No more." No more what? No more sleep? But sleep is a consummation devoutly to be wished. I think that the answer is that Hamlet came in reading, as he had in Act II, scene 2. When he came to "To sleep" he turned over the document to see if there was any more on the back. There was not. So he said so, and turned it over again, and went back to the last words, "To die. To sleep." The question is: what was he reading when he said "To be or not to be, that is the question"? 


\section{DAVID PUGSLEY}

Shakespeare, William (1623) Cymbeline

Shakespeare, William (1623) Hamlet

Shakespeare, William (1623) King Lear

Shakespeare, William (1623) Macbeth

Shakespeare, William (1623) Titus Andronicus

Shearman, Montague (1925) "The Western Circuit in the 16th Century" The Dorset Yearbook (1925): 24-26

Strazicker, Elizabeth (2007) The Sheriffs of Cambridgeshire and Huntingdonshire: A Brief History (Cambridge)

\section{Newspapers}

The Times, 7 September 1798

The Times, 12 August 1806

Exeter Flying Post, 22 January 1824.

The Times, 14 November 1905

British Newspaper Archive

Times Digital Archive

\section{Film}

Branagh, Kenneth (1996) Hamlet

\section{Case law}

Lansbury v Riley [1914] 3 KB 229

\section{Legislation}

Justices of the Peace Act 1361, 34 Edward III, cap 1, Ex magno Rot Stat in Turr, London, $m 10$ 